\title{
Da udenrigsministeren stod uden for døren
}

\section{Rasmus Brun Pedersen og Flemming Juul Christiansen}

\section{Politisk drilleri da SF's udenrigsminister måtte}

vente uden for døren, peger på principielle overvejelser om parlamentarisk kontrol med udenrigsog sikkerhedspolitikken og den autonomi, den danske regering normalt ventes at have på dette 'særlige' politikområde

Da den nyudnævnte udenrigsminister Villy Søvndal (SF) pænt måtte vente udenfor, mens forligskredsen bag Afghanistan-missionen diskuterede, om de ville lade SF komme med i aftalen, udstillede forløbet en række interessante problemstillinger i forhold til den virkelighed, danske mindretalsregeringer arbejder under. Socialistisk Folkeparti og Enhedslisten var de eneste partier i Folketinget, der stod uden for Afghanistan-forliget, og ifølge almindelig praksis kan et parti ikke bare træde ind, medmindre alle forligspartierne godkender det.

Forligskredsen skulle således uden Socialistisk Folkeparti diskute- re, om partiet - som regeringsparti - kunne komme med i forliget. Inklusionen af SF i forliget har været mødt af skepsis i de borgerlige partier pga. SF's tidligere modstand imod beslutningsgrundlaget for Afghanistan-indsatsen. Dette var senest udtrykt ved, at partiet i december 2008 stemte imod en folketingsbeslutning om at styrke det danske bidrag. Dansk Folkeparti har tilmed krævet, at SF og Villy Søvndal som udenrigsminister ikke kan sidde for bordenden, hvis de kommer med i forliget, selvom SF ellers i forhandlingerne om regeringsgrundlaget har accepteret Afghanistan-missionen. Derved kan Danmark i princip- 
pet havne i den lidt absurde situation, at landets udenrigsminister ikke kan indgå i drøftelser vedrørende den fremtidige danske deltagelse i Afghanistan-missionen.

Drøftelsen blandt forligskredsens medlemmer er endnu ikke afsluttet, men ender formentligt med at Socialistisk Folkeparti som nyt regeringsparti automatisk indgår i kredsen, ligesom praksis er på andre politiske områder, der er forligsbelagte.

Mens drøftelserne om Socialistisk Folkeparti og Afghanistan kan opfattes som almindeligt politisk drilleri mellem regering og dele af oppositionen, rejser forløbet en række principielle overvejelser vedrørende den parlamentariske kontrol med udenrigs- og sikkerhedspolitikken og den autonomi, den danske regering traditionelt forventes at have på dette 'særlige' politikområde, sammenholdt med Folketingets praksis omkring at indgå i politiske forlig.

Traditionelt betragtes udenrigspolitikken som regeringens område, men den danske tradition for mindretalsregeringer medfører en hyppig og omfattende parlamentarisk koordinering for at sikre, at regeringen altid har et flertal bag, og at Danmark som småstat altid kan optræde samlet internationalt. Det forhold, at dele af udenrigspolitikken ofte er forligsbelagte, er imidlertid et forhold der oftest glemmes i den offentlige debat om den danske udenrigs- og sikkerhedspolitik.

Analysen her sætter betydningen af politiske forlig og udenrigspolitik i perspektiv af dansk parlamentarisme generelt ud fra to forhold. For det første at regeringen ifølge Grundloven har brug for Folketingets aktive samtykke i nogle sager, men ikke i andre. For det andet at litteraturen om dansk indenrigspolitik viser, at politiske forlig forekommer hyppigere, når en regering føler sig truet. Artiklens formål er på denne baggrund at belyse, hvornår og hvordan Folketinget og regeringen forpligter hinanden om udenrigspolitikken, herunder i form af politiske forlig.

\section{Grundloven og udenrigspolitik}

Hvis den danske regering ønsker at gennemføre en lov, skal et flertal i Folketinget stemme for den. Folketingets aktive tilslutning er dermed nødvendig. Historisk adskiller udenrigspolitik sig fra indenrigspolitik ved at give regeringen et større spillerum til at handle i udenrigspolitikken. Det gælder også i den danske grundlov, hvor det ifølge $§ 19$ er regeringen, som fastlægger Danmarks position i internationale sammenhænge, uden at det kræver lovgivning. Dog skal regeringen indhente samtykke fra Folketinget i en række situationer. Det gælder ændringer af Danmarks grænser, traktater, anvendelsen af militære magtmidler samt forpligtelser, hvis opfyldelse vil kræve Folketingets samtykke. Derudover har regeringen pligt til at rådføre sig 
med Folketingets Udenrigspolitiske Nævn om større beslutninger.

I EU-samarbejdet er regeringen i tiltrædelsesloven fra 1972 med senere ændringer overladt kompetence til at forhandle på Danmarks vegne, idet den dog skal underrette et folketingsudvalg "om forslag til rådsvedtagelser, der bliver umiddelbart anvendelige i Danmark, eller til hvis opfyldelse Folketingets medvirken er nødvendig”. Regeringen er ikke retligt, men alene politisk bundet af forhandlingsmandater fra Europaudvalget, tidligere Markedsudvalget.

Modsat indenrigspolitikken har Danmark dermed grundlæggende to forskellige beslutningsformer i udenrigspolitikken. I den ene kræves Folketingets aktive tilslutning ligesom i indenrigspolitikken. I den anden har regeringen ret til at handle på egen hånd, selvom den i vigtige sager har pligt til at informere og lytte til Folketinget, men ingen forpligtelse til at følge dettes instrukser.

\section{Parlamentarismen}

Når regeringen selv kan træffe beslutninger uden at skulle påvise et flertal i Folketinget, vil den have lettere ved at komme igennem med sin politik sammenlignet med møjsommeligt at skulle opbygge et flertal og indgå kompromis. Det gælder særligt for danske regeringer, der som regel er i mindretal og dermed behøver støtte fra partier uden for regeringen for at kunne opnå flertal.
Medaljen har imidlertid en bagside, for parlamentarismen som er hjemlet i Grundlovens $§ 15$, sikrer at et flertal i Folketinget altid kan vælte regeringen. Hvis regeringen ikke på forhånd har taget Folketinget $\mathrm{i}$ ed, forøges risikoen for at vække dettes mishag, hvilket kunne udløse et mistillidsvotum. Bestemmelserne i Grundloven om Folketingets inddragelse bør dermed ikke kun opfattes som en kontrol af regeringen, men også som en mulighed for den til at vejre stemningen i Folketinget og opnå større sikkerhed for, at den ikke kommer til at foretage sig noget, der giver anledning til at blive væltet.

Imidlertid vil et oppositionspartis overvejelser om at vælte en regering afhænge af en helhedsvurdering af, om regeringens overlevelse er i dens interesse i den aktuelle situation.

Denne helhedsvurdering vil også medinddrage mange andre forhold end de udenrigspolitiske. Hvis en sådan vurdering falder ud til fordel for regeringen, opnår den alligevel et større handlerum, end hvis den aktivt skal påvise et flertal i en afstemning. Eksempelvis støttede Dansk Folkeparti VK-regeringen fra 2001 til 2011 på trods af, at partiet var uenig med regeringens politik i forhold til EU, som regeringen dog havde flertal for med andre partier. Regeringen kan imidlertid ønske at kende til Folketingets mening for at undgå kritik i offentligheden fra oppositionspartier, der vil kunne skade 
regeringens offentlige tilslutning. Sådanne angreb hører til et af oppositions vigtigste magtmidler. Jo mindre kontrol, regeringen selv har over, hvordan en sag vil forløbe, jo større risiko er der for, at noget uforudset dukker op, som oppositionen kan angribe regeringen med.

Da regeringen i internationale sammenhænge netop kun er én aktør blandt flere, er denne risiko til stede som følge af andre aktørers initiativer. Eksempelvis kan det være vanskeligt for regeringen at vide præcist, hvilke forslag, som kommer fra EU, hvilket i princippet kan øge usikkerheden om, hvorvidt disse forslag kan vedtages i det danske Folketing. Ligeledes er forløbet af militære aktioner notorisk forbundet med usikkerheden og risiko for tab af menneskeliv, der vil kunne koste offentlig sympati.

Set fra regeringens side er to modsatrettede hensyn dermed i spil. For det første hensynet til det politiske indhold, hvor det er attraktivt at kunne gennemføre sin egen politik, men for det andet hensyn til Folketingets flertal i forhold til at forblive i regering og reducere risikoen for kritik i offentligheden, der kan koste stemmer ved næste valg.

Det er netop, når regeringen og et antal politiske partier i Folketinget ønsker at træffe beslutninger i situationer præget af politisk usikkerhed og konkurrence, at de forsøger at 'binde' hinanden politisk i form af politiske forlig. De udgør et sæt af parlamentariske spilleregler omkring at gennemføre og opretholde politiske beslutninger over et vist tidsrum.

Dette indebærer blandt andet, at forligspartierne medinddrages forud for beslutninger på det aftalte område, og at de giver hinanden vetoret i forhold til at ændre beslutninger. Forligene kan gælde både på tværs af valg og efter regeringsskifter. Reglerne er uformelle, da de hverken er nævnt i Grundloven eller Folketingets forretningsorden. Ligeledes vil en minister ikke kunne blive dømt efter ministeransvarlighedsloven for at bryde et forlig, som alene opfattes som politisk bindende. Regeringen kan imidlertid bruge politiske forlig til at handle med: Til gengæld for at opnå stemmer og forøget sikkerhed i forhold til at overleve parlamentarisk, tildeler regeringen oppositionspartier indflydelse på den førte politik og i tillæg de nævnte uformelle proceduremæssige rettigheder i forhold til at ændre på den førte politik.

I udenrigspolitikken er Folketingets aktive tilslutning kun nogle gange nødvendig, hvormed den ligner dansk indenrigspolitik, mens den i andre tilfælde ikke er nødvendig og dermed adskiller sig. Alligevel forventer vi, at når regeringen er usikker på en sags forløb, har den gode grunde til at forsøge at forpligte Folketingets partier, uanset om den konstitutionelt selv må træffe afgørelserne eller ikke. Vi kan derfor 
systematisk analysere de to situationer inden for samme politikområde ud fra, om - og i givet fald, hvornår og hvordan - regeringen forsøger at binde Folketingets partier. Vores forventninger er sammenfattet $i$ tabel 1.

Vi vil i det følgende forsøge at illustrere, hvordan en række forskellige udenrigspolitiske beslutningsforløb svarer til de forventninger.

\section{Folketinget skal med}

Når den danske regering har brug for Folketingets tilslutning, sker det typisk ved, at dette vedtager et beslutningsforslag fremsat af udenrigsministeren. I alt har vi opregnet de 16 beslutningsforslag, som blev vedtaget i Folketingets seneste valgperiode fra 2007 til 2011 vedrørende udenrigspolitik. Otte af beslutningerne angik militære engagementer, mens otte angik Danmarks indgåel- se af traktater. For tre af disse beslutninger har det været muligt for os at påvise, at Folketingets partier indgår i en forligskreds, ligesom de kendes fra dansk indenrigspolitik. Det gælder angående den danske deltagelse i de militære aktioner i Afghanistan og i Libyen. Det gjaldt for ingen af tilfældene angående ratificering af traktater.

Debatten under Folketingets førstebehandling af beslutningsforslagene om Afghanistan (B140 fra Folketingets 2007-2008 II-samling og B24 fra 2008-2009-samlingen) viste, at der lå en politisk aftale til grund. 22. februar 2011 indgik udenrigs- og forsvarsministrene den nugældende Aftale om den danske indsats $i$ Afghanistan: Helmand planen 20112012 med de daværende regeringspartier Venstre og Det Konservative Folkeparti samt Socialdemokraterne, Dansk Folkeparti, Radikale Venstre og Li-

Tabel 1. Forventninger til regeringens adfard $i$ forhold til at forpligte Folketinget $i$ dansk udenrigspolitik.

\begin{tabular}{|l|l|l|}
\hline & $\begin{array}{l}\text { Folketingets tilslutning } \\
\text { nødvendig }\end{array}$ & $\begin{array}{l}\text { Folketingets tilslutning } \\
\text { er ikke nødvendig }\end{array}$ \\
\hline Politisk ufarligt & $\begin{array}{l}\text { Regeringens fremlægger } \\
\text { sine forslag for Folketin- } \\
\text { get uden forhåndsbin- } \\
\text { dinger }\end{array}$ & $\begin{array}{l}\text { Regeringen handler på } \\
\text { egen hånd }\end{array}$ \\
\hline Politisk risikabelt & $\begin{array}{l}\text { Regeringen indgår forlig } \\
\text { med oppositionspartier } \\
\text { om love eller beslut- } \\
\text { ningsforslag }\end{array}$ & $\begin{array}{l}\text { Regeringen inddrager } \\
\text { og forsøger at opnå støt- } \\
\text { te fra Folketinget }\end{array}$ \\
\hline
\end{tabular}


beral Alliance. Aftalen er fem sider lang og specificerer forholdsvis detaljeret en række aspekter omkring den danske indsats. Det er på baggrund af denne aftale, at der efter valget i 2011 opstod den offentlige debat omtalt i indledningen, om SF skulle være en del af forligskredsen, når nu partiet er kommet i regering og tilmed besætter udenrigsministerposten. Formatet med forligstekst samt diskussionen vedrørende SF's deltagelse viser, at den danske indsats i Afghanistan er reguleret, som var det et vanligt politisk forlig.

I forhold til den danske deltagelse i den internationale, militære aktion i Libyen i 2011, som forsvarsalliancen NATO endte med at stå for, har der ligeledes været tale om, at der fandtes en forligskreds bestående af alle Folketingets partier på nær Enhedslisten, der har fulgt begivenhederne og undervejs støttet op om at fortsætte den danske indsats trods bekymringer over omkostningsniveauet.

Begge forløb viser, at danske mindretalsregeringer også undertiden forpligter sig med partier uden for regeringen i politiske forlig i forbindelse med dansk udenrigspolitik. Vi har dog her kun konstateret dem ved beslutninger om militære aktioner og ikke i forbindelse med indgåelse af internationale traktater og lignende. Da militære aktioner i sagens natur er forbundet med større usikkerhed og offentlig opmærksomhed end traktater, der måske snarere kan forekomme offentligheden noget støvede, burde vi forvente, at regeringen har mere brug for at binde sig og indgå i politiske aftaler med Folketingets partier i forbindelse med militære aktioner.

Desuden er påvist eksistensen af en forligslignende 'EU-koalition' af partier i Folketinget, fra 2004 bestående af Venstre, Socialdemokraterne, Radikale Venstre, Socialistisk Folkeparti og Det Konservative Folkeparti, som på tværs af regeringsskift tager ansvaret for at gennemføre beslutninger om EU, der kræver Folketingets medvirken i form af lovgivning. De fem partier agerer med udgangspunkt i en langsigtet europapolitisk aftale fra 2004, som blev fornyet i 2008. Analysen viser, at regeringen inddrager en kreds af Folketingets partier på denne tætte måde, fordi de i modsætning til indenrigspolitikken ikke har fuld kontrol over indhold og timing af EUlovgivning.

\section{Folketinget ikke med}

Regeringen træffer afgørelserne i udenrigspolitikken, men den skal orientere og rådføre sig med Udenrigspolitisk Nævn, dvs. lytte til og besvare dets spørgsmål. På linje med andre udvalg under Folketinget har Nævnet også adgang til at føre parlamentarisk kontrol med regeringen. Ligeledes kan andre udvalg, i praksis især Udenrigs- og Forsvarsudvalgene, stille regeringen til ansvar for 
dens udenrigspolitiske gøren og laden. På denne måde finder regeringen ud af, om den har parlamentarisk opbakning til sin linje. Regeringens ministre har eksempelvis det afgørende ord i forhold til, hvordan Danmark stemmer på De Forenede Nationers generalforsamling, eller handler på vegne af Danmark i Nordisk Ministerråd. Politiske forlig lader ikke til at spille nogen rolle for denne del af udenrigspolitikken.

Danske regeringer og Folketingets partier kan forpligte hinanden på andre måder end i politiske forlig. Det gælder blandt andet i forbindelse med 'vedtagelser', hvori Folketinget efter en forespørgselsdebat eller en redegørelse fra en minister til Folketinget kan opfordre regeringen til at følge en bestemt politisk linje. I perioden i 1980'erne med de såkaldte alternative flertal uden om regeringen under Schlüters regeringerne kunne der opstå en konflikt mellem regeringens adfærd og Folketingets flertal. Bortset fra denne særlige periode støtter regeringspartierne typisk selv, hvad Folketinget vedtager. På den måde kan de benyttes til at påvise, at regeringen nyder Folketingets aktive opbakning til en bestemt politisk linje.

Særligt vedrørende EU gælder, at Europaudvalget forud bliver inddraget i beslutningsgrundlagene for regeringens forhandlinger. Det sker i form af en procedure, hvorunder regeringen søger et forhandlingsmandat, som den opnår, hvis der ikke er et flertal imod det, talt ud fra størrelsen i folketingssalen af de repræsenterede partier (Beretning fra Markedsudvalget, afgivet 29. marts 1973). Proceduren afspejler dermed, at regeringen ikke behøver Folketingets samtykke, men omvendt behøver Folketingets tillid for at kunne blive siddende. Det følger af den negative form for parlamentarisme, der gælder i Danmark.

Det forekommer sjældent, at regeringen ignorerer eller beskyldes for at ignorere Europaudvalget. Tværtimod opfattes dette udvalg med en betydelig ærefrygt, og ministre har snarere tendens til at søge et mandat, hvor det ikke strengt taget var nødvendigt, end omvendt.

\section{Konklusion}

Regeringen inddrager i en række tilfælde Folketinget ud over, hvad Grundloven påkræver. Det gælder især omkring EU-samarbejdet, hvor den opnår støtte til sine forhandlingsmandater i Europaudvalget, men også i forhold til at Folketinget, typisk med støtte fra regeringspartierne, i vedtagelser fastlægger en politisk linje i en række spørgsmål.

Dog finder vi kun egentlige politiske forlig om udenrigspolitik, hvor regerings- og oppositionspartier forpligter hinanden, når regeringen rent faktisk har brug for Folketingets samtykke. Så på trods af parlamentarismen, ifølge hvilken Folketinget til enhver tid kan vælte rege- 
ringen, så gør det en forskel, at udenrigspolitikken i en række tilfælde er et anliggende, som regeringen træffer de endelige beslutninger om.

Danske regeringer forekommer mere tilbøjelige til at inddrage en kreds af Folketingets partier med et flertal bag sig på en forpligtende langsigtet måde, når en sag rummer en risiko for regeringen enten i forhold til at overleve eller tabe støtte i offentligheden. Vores materiale tyder på, at dette er tilfældet, både når Folketingets samtykke er påkrævet, og når det ikke er det.

I den første situation fandt vi, at politiske forlig spillede en rolle for knap halvdelen af beslutningerne om dansk militært engagement, men ikke for godkendelsen af traktater, og militære operationer må regnes som mere risikable og uforudsigelige end at medvirke til en traktat. I den anden situation fandt vi som nævnt stærkt partipolitisk forpligtende og forligslignende samarbejde omkring EU-mandaterne, hvor regeringen ikke har kontrol over, hvordan sagen forløber, og i $\emptyset$ vrigt kan forvente at have brug for Folketingets aktive støtte efterfølgende til at implementere EU-beslutninger som dansk lovgivning.

Når Folketinget i form af vedtagelser, som nævnt typisk med regeringens støtte, tilkendegiver Danmarks holdning til aspekter af udenrigspolitikken, så angår det større og overordnede emner, hvortil det kan opfattes som en fordel for regeringen i forhold til at bestå parlamentarisk at kende til Folketingets linje. Sådanne vedtagelser efterlader dog alligevel et spillerum til regeringen.

Tilsvarende gælder for regeringens inddragelse af Det Udenrigspolitiske Nævn, at den her sonderer holdningen i Folketinget, og beskrivelser tyder på, at danske regeringer er meget ivrige efter at skaffe sig opbakning til sin position. Så selv når den danske regering ikke behøver Folketingets samtykke, søger den alligevel at sikre sig støtte fra et flertal. Mindretalsstatus lader til i praksis at veje tungere end regeringens juridiske ret til at føre udenrigspolitikken på egen hånd.

Danske regeringers behov for at skaffe sig parlamentarisk dækning er ikke kun begrundet i interne danske parlamentariske forhold. De har også praktisk betydning i forhold til, når den danske regering forhandler internationalt. Særligt i forhandlinger med op til flere andre lande er det en fordel at kunne byde ind og slå til på det rigtige tidspunkt, og da har danske regeringer brug for troværdigt at kunne signalere til sine potentielle aftalepartnere, at de på trods af deres mindretalsstatus har dækning for, hvad de foreslår og kan gå med til. Inddragelse af Folketinget medvirker hertil.

Rasmus Brun Pedersen og Flemming Juul Christiansen, adjunkter, Institut for Statskundskab, Aarhus Universitet. 